\title{
IAMJ
}

INTERNATIONAL

AYURVEDIC

MEDICAL JOURNAL

\section{AMA FROM AYURVEDIC AND MODERN PERSPECTIVE}

\author{
Archana Arun Kulkarni ${ }^{1}$, Rashmi Arvindkumar Dohare ${ }^{2}$ \\ ${ }^{1}$ Professor, Rog Nidan Dept., \\ ${ }^{2}$ Lecturer, Sharir Kriya Dept. \\ BSDT's Ayurved College, Wagholi, Pune, Maharashtra, India
}

Corresponding Author: archana.arukulkarni@gmail.com

https://doi.org/10.46607/iamj2109122021

(Published Online: December 2021)

Open Access

C International Ayurvedic Medical Journal, India

Article Received: 15/11//2021 - Peer Reviewed: 07/12/2021 - Accepted for Publication 08/12/2021

\section{Check for updates}

\section{ABSTRACT}

Agni is one of the most powerful transformative principles of Ayurveda. Deranged Agni leads to the formation of Ama. Ama is responsible for causing most of the diseases in human beings. The disease produced, clinically manifests itself in form of various signs and symptoms. These signs and symptoms are the principal tools for a physician to diagnose the disease and treat it promptly. On the basis of these symptoms, all diseases can be classified in Samavastha and Niramavastha. If an objective Parameter that could measure the severity of Ama is searched, it will prove to be an advantage for the physician, who could then catch the cause (Ama) and save patients from this harmful disease entity. A definite line of treatment of Ama can be planned after considering the symptoms and severity of the condition. Keeping this approach, the review is carried out to understand Ama from Ayurvedic and Modern perspectives. After reviewing it can be concluded that Ama has no direct correlation in modern science but can best be equated to 'toxins'. They may be endotoxins like enzymes, hormones, catalysts, etc. when these are unable to function properly or entirely, different metabolites are formed which are not acquired by the body. On further process these go on accumulating in different systems, affecting the normal mechanism of that respective system or exotoxins produced by some bacteria or micro-organism when they enter into the body.

Keyword: Agni, Ama, Toxin 


\section{INTRODUCTION}

Health is the supreme foundation of virtue, wealth, enjoyment and salvation. Acharya Caraka has mentioned the general principles for maintaining health. These include observing various measures like following a dietic and behaviouristic regimen of life according to Desa, Kala and Prakruti, avoidance of Sahasa, Asatmayaindriyartha Samyoga etc.

Agni is one of the most powerful transformative principles of Ayurveda. It holds the secret to longevity, vitality, life force, good health, more energy, clarity of mind, and wellness. ${ }^{[1]}$ The main function of Agni pertains to digestion, absorption, assimilation, and conversion of food into energy.

Deranged Agni, causing impaired digestion and metabolism, leads to the availability of incompletely processed food components and metabolites in the system. These substances which bear a threat to the health of a person are designated as Ama. The majority of the endogenous diseases actually begin with the formation of Ama, which has a tremendous capacity to vitiate the Doshas, thus disturbing the homeostasis (Dhatu-Samya). In addition to hypo functioning of Agni, caused due to abstinence from food, indigestion, overeating, irregular diet habits, consumption of cold substances, ill effects of Panchkarma, wasting of tissues, suppression of natural urges and mental stress such as anger, grief and hunger etc. may also give rise to Amadosha.

The disease has been referred to as Vyadhi in Ayurveda. Nearly all diseases as per the Ayurvedic view have their origin from Amadosha. Even one of the synonyms of Vyadhi is Amaya which indicates it. ${ }^{[2]}$

Ama can be considered as an undigested or partially digested metabolised substance that requires further Parinamana and if retained as such, it may produce impairment in the micro and macro channels of the body. It ultimately creates the condition of Srotavaigunya or the seat for the accumulation of the provoked Doshas converting it into the form of any disease. It may be the cause why Ayurveda has given much importance to the concept of Ama than Amaya. Ama both at acute, sub-acute or chronic conditions appear to relate to the gastrointestinal as well as met- abolic disturbances engender due to impairment of Antaragni.

The Ama thus formed manifests itself either locally (Gastrointestinal Tract) or systemically by obstructing the macro and microchannels. The disease thus produced, clinically manifests itself in form of various signs and symptoms. These signs and symptoms are the principal tools used by a physician to diagnose the disease and treat it promptly.

Ama and various diseases produced by it may be identified or diagnosed by looking for a number of subjective symptoms, which have been described in various Ayurvedic classics. But with the recent trends of thinking, the latest approach to the study of the physiological as well as pathological states of human beings has been directed more to the parameters which are better understood either by direct cognition or inference based on laboratory investigations done in vitro.

Just as to confirm diabetes mellitus by increased blood glucose level or jaundice by increased bilirubin level or malaria by seeing the malarial parasite in the peripheral smear, similarly we should be able to elicit a specific moiety in vitro which could confirm the prevalence of Ama in the body. Thus, if an objective Parameter that could measure the severity of Ama is searched for, it will prove to be a boon for the physician, who could then catch the culprit (Ama) and save their patients from this detrimental disease moiety.

Keeping this approach of the modern view in mind, the review is carried out to understand Ama from Ayurvedic and modern perspectives.

\section{REVIEW OF LITERATURE}

\section{NIRUKTI OF AMA: -}

According to Shabdakalpadruma: ${ }^{[3]}$

The word Ama refers to substances subjected to digestion.

According to Vachaspatyam: ${ }^{[4]}$

The word Ama is derived from "Am" Dhatu with the suffix " $a$ ", which means improper or partially digested matter.

So, a substance that harms the normal healthy state of the body, or any part of the body can be considered as 
Ama. Therefore, depending upon etymology Ama can be described as - raw, uncooked, unripe, immature, undigested or incompletely oxidised/metabolised or similar to a poisonous substance.

\section{DEFINITION OF AMA: -}

Though the diseases associated with Ama have been described by authors like Caraka and Susruta; but Vagbhata is the first author to define Ama as a separate entity. According to him Due to the hypo function of Ushma (Agni), the food, which is not completely or properly digested, yields immature Rasa in Amashaya and due to its retention, undergoes fermentation or putrification. ${ }^{[5]}$

An impaired Vatadidosha after mixing up with each other produce Amavisha like the Visha produced after the fermentation of Kodrava. As prior to fermentation in Kodrava there was no Visha similarly prior to the vitiation of Vatadi Dosha there was no Ama. ${ }^{\left[{ }^{6}\right.}$

There is no direct definition of Ama available in Carak Samhita but in the fifteen ${ }^{\text {th }}$ chapter of Chikitsa sthana while describing Samprapti of Grahani Roga indirect reference of Ama is available. i.e., due to $\mathrm{Ni}$ dana Sevana when Agni is vitiated, it becomes incapable of digesting the ingested food, and this undigested food after getting fermented turns into a poisonous substance. ${ }^{[7]}$

The definition of Ama given by Bhavamisra in the $16^{\text {th }}$ century is if food is not digested properly due to hypofunction of Agni gets the name Ama and becomes the root cause of many diseases. ${ }^{[8]}$

Due to the weakness of Kayaagni, the Ahara rasa is not properly formed in the Amashaya and this state, it is known as Ama. In another sense, it is also told that the first Dhatu i.e. Rasa Dhatu, if not formed properly, then this first unconverted Rasa dhatu is termed as Ama.
Again, the next definition of Ama Acahrya Vijayaraksita stated that due to the feebleness of Agni a residue of Ahararasa is still left as undigested. It is then known as Ama, which is the root cause of all diseases.

Here are the three different opinions about Ama which are compiled by Vijayaraksita.

The first view is about the improperly digested food, the second describes the accumulation of Malas in the different parts of the body termed as Ama. The third view is about the stages of Dosha Dushti or disease, which says the first stage of Dosha Dushti or disease is Ama. ${ }^{[9]}$

\section{SYNONYMS OF AMA: -}

The varieties of meaning according to different classics: incomplete digested matter, partially digested matter, unprocessed matter, a matter which requires further digestion, Matter which is subjected to Parinamana.

\section{NIDANA OF AMA: ${ }^{[10]}$}

It can be categorized into following criteria:

\section{Aharajanyanidana}

\section{Viharajanyanidana}

3.Manasikanidana

\section{Mithyopacharajanha nidana.}

Other causative factors for Ama formation:-The quantum of food is not the only cause of the formation of Ama (undigested and non-metabolized food) in the body but also the use of diet and drinks which are heavy to digest, and with properties like dry, cold, dehydrated, disliked by the consumer, constipationcausing, causing a burning sensation, unclean, incompatible, and/or consumed untimely. Intake of food while the mind is afflicted with passion/desires, anger, greed, infatuation, envy, bashfulness, grief, conceit, excitement and fear are also the cause of the formation of Ama.

Table 1: Showing Nidana leading to Ama formation

\begin{tabular}{|l|l|l|l|}
\hline Aharajanya Nidana & Viharajanya Nidana & Manasika Nidana & $\begin{array}{l}\text { Mithyopacharajanha } \\
\text { Nidana }\end{array}$ \\
\hline $\begin{array}{l}\text { 1.Intake of Atimatra Ahara, } \\
\text { 2. Fasting for a long time. }\end{array}$ & Vega Sandharana, & If a person, afflicted & Incorrect management \\
3. Untimely ingestion of Annapana & Swapna Viparyaya & with Irshya,Bhaya, Krodha, & of Vamana, Virechana or \\
\hline
\end{tabular}




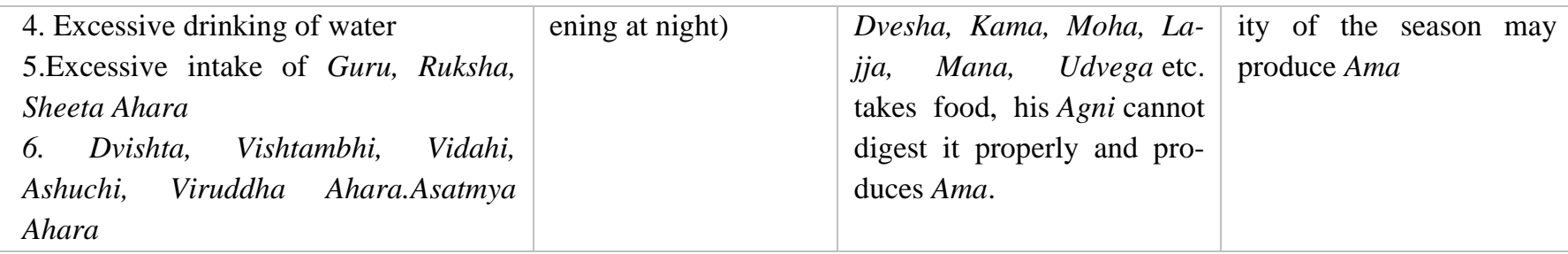

\section{TYPES OF AMA: -}

The main causative factor for the production of Ama is Mandagni at different levels. So Ama can be classified into the following types: -:

a. Jatharagnimandya janit ama

b. Dhatwagnimandya janit ama

c. Doshadushya sammurcchana janit ama

d. Malasamchaya Janya ama.

e. Krumi vishjanya ama.

a. Jatharagnimandya janit ama: - Acharya Vagbhatta explained that when the normal functioning of Jatharagni gets impaired due to any cause, it leads to indigestion of food and formation of improper Ahara Rasa Dhatu which gives rise to Ama.

b. Dhatwagnimandya janit ama: Dhatwagni is that part of Pachakagni or Jathragni, which is present in Dhatus and helps in their formation. Each Dhatu has separate Dhatwagni. Any disturbance in Jathargni also affects the Dhatwagni. This causes improper formation and functioning of Dhatus and production of Ama.

c. Dosha dushya sammurcchana janit ama or Interaction or amalgamation between vitiated Dosha and Dushya: - Every Dosha has certain qualities, which are antagonistic to the qualities of other Doshas. e.g., the dry and light qualities of Vata are antagonistic to the oily and heavy qualities of Kapha. Similarly, the hot quality of Pitta is antagonistic to the cold quality of Kapha and Vata. Therefore, when two or three doshas become severely vitiated they produce interaction between them. In such conditions opposite qualities, instead of nullifying each other interact and produce a toxic substance. The amalgamation of Dosha and Dushya gives rise to the production of Ama.

d. Malasamchaya Janya Ama: According to Madhavakara, Ama is an accumulation of Mala in the body. As per the Ayurveda concept, Mala are of two types i.e Sthula Mala and Sukshma Mala. The excess quantity of these Malas causes adverse effects on digestion and metabolism and may be acclaimed as Ama.

e. Krumi vishjanya ama: - In this category, the Ama $i s$ produced by ingestion of poisonous substances and produced due to external factors. Even the endotoxins produced by some bacteria or micro-organisms can be termed as Ama.

Effect of Ama: -Acharya Vagbhtta has explained that Sama is the term rendered to afflicted Tridosha, Sapta Dhatus and Mala by Ama. ${ }^{[11]}$ Diseases that arise in consequence are also termed as Sama type of disease. Ama is capable to vitiate Dosha, Dhatu Mala and producing diseases. Sama Dosha can spread to all Rogamarga and can move from Shakha to Koshtha and vice versa. Ama circulates in the body along with Rasa Dhatu and accumulates in a place where Kha Vaigunya is present and produces the disease.

SWAROOPA OF AMA: - [12]

In this definition, the nature and symptoms produced by Ama have been described. Ama is the substance that remains Avipakva (undigested), Asamyukta (disintegrated), Durgandhi (foul-smelling), $B a$ $h u$ (excessive in quantity), Picchala (slimy) and causes Sadana (stiffness) of the whole body.

The above properties can be classified in the following ways -

(1) Properties which can be felt by touch: -

Dravatva, Picchilatva and Snighdhta

(2) Properties which can be perceived by eyes: -

Tantumatta, Avipakvata, Asamyuktata, Anekavarnayuktat and Picchilata

(3) Properties that can be perceived by smell: - Durgandha

(4) Properties which can be known by questioning: Guruta and Avipakvata 
VIKRUTA SAMAVASTHA: - Due to Agni Dushti at the level of Jatahragni, Bhutagni or Dhatwag$n i$, Ama is produced. This is the condition when Ama produced in the body gets adhere to normal Dosha, Dushyas and Malas and impairs their normal func- tioning or when Ama produced in the body gets associated with Vata then it is termed as Samavata. Though there is no structure-wise deformity in the Dosha-Dushya and mala due to the Ama, they are unable to perform normal functions and show a state of Vikruti.

Table 2:- Samadoshadi lakshana

\begin{tabular}{|c|c|c|}
\hline Dosha & Lakshana & Co-relation \\
\hline Vata & $\begin{array}{l}\text { Agnimandya, Vibandha, Tandra, Antrkunjana, } \\
\text { Angamarda, Angashotha, Angatoda, Adhmana, An- } \\
\text { gagraha, Staimitya, Gaurava, Aruchi, Alasya, Sha- } \\
\text { ityata,Katuruksabhilashi, Arti, Balanasha, Va- } \\
\text { rananasha, Sukhanasha, Ayunasha. Along with } \\
\text { these increases in the symptoms of Vata after } \\
\text { Snigdhadi Upkramas, during sunrise, cloudy at- } \\
\text { mosphere and night are described as the symptoms } \\
\text { of Samavata. }\end{array}$ & $\begin{array}{l}\text { Some of the above mentioned } \\
\text { Symptoms can be seen in patients of Sama Jwara. }\end{array}$ \\
\hline Pitta & $\begin{array}{l}\text { Haritavarna, Ishatkrishnavarna, Shyava Varna, } \\
\text { Amlarasa, Sthiratva, Sandrta, Amlodgara, } \\
\text { Kanthdaha, Hruddaha, Durgandha, Katukatva, } \\
\text { Bahalatva, Ghanata, Daha, Trushnabahulata, } \\
\text { Mukhpaka }{ }^{[13]}\end{array}$ & $\begin{array}{l}\text { When due to the presence of Ama in the gastrointestinal } \\
\text { tract normal digestive juices are not able to digest food. }\end{array}$ \\
\hline Kapha & $\begin{array}{l}\text { Avilta, Tantumana, Picchilata, Sandrata, Dur- } \\
\text { gandhita, Kanthaliptata }{ }^{[13]}\end{array}$ & $\begin{array}{l}\text { In Rheumatoid arthritis, Ama produced in the body goes to } \\
\text { the site of Sleshaka Kapha i.e., in Sandhis (joints) and ad- } \\
\text { heres with Sleshaka Kapha present there and thus impairs its } \\
\text { functions. }\end{array}$ \\
\hline Rasa & $\begin{array}{l}\text { Ashradha, Aruchi, Mukhvairasyata, Arasagyata, } \\
\text { Trupti, Hrullasa, Gaurava, Tandra }{ }^{[14]}\end{array}$ & $\begin{array}{l}\text { Stage of Sama Rasa can be seen clinically in the case of } \\
\text { lymphadenitis in which due to any infection, exo- or endo- } \\
\text { toxins are produced in lymph and filtered by lymph nodes } \\
\text { and as result lymphadenitis is produced. Due to swelling and } \\
\text { excessive filtration in lymph glands, further flow of lymph } \\
\text { is obstructed and fever, anorexia, malaise etc. symptoms are } \\
\text { produced in the body. }\end{array}$ \\
\hline Rakta & $\begin{array}{l}\text { Kustha, Visarpa, Pidika, Raktapitta, Asrugdara, } \\
\text { Gudapaka, Medhrapaka, Mukhapaka, Plihavruddhi, } \\
\text { Gulma, Vidrdhi, Nilika, Vatarakta, Arsha }{ }^{[14]}\end{array}$ & $\begin{array}{l}\text { Introduction of unwanted substances in the blood like endo- } \\
\text { exotoxins can be considered as Samarakta Dhatu Avastha in } \\
\text { which actions of blood becomes disturbed due to additional } \\
\text { substances present in it. }\end{array}$ \\
\hline Mansa & $\begin{array}{l}\text { Mansarbuda, Adhimansa, Keela, Granthi, Adhi- } \\
\text { jivha, Taluvikara, Upajiwha, Kantha Roga, Upaku- } \\
\text { sha }{ }^{[14]}\end{array}$ & $\begin{array}{l}\text { When much amount of lactic acid is accumulated in Mansa } \\
\text { the condition can be considered as Samamansa Dhatu be- } \\
\text { cause in this case there is no deformity in Mansa Dhatu but } \\
\text { because of the presence of lactic acid, severe pain and loss } \\
\text { of function is produced. }\end{array}$ \\
\hline Meda & $\begin{array}{l}\text { Presence of prodromal signs of Prameha, Sthaulya, } \\
\text { Gaurava, Atisweda, Arbuda. }{ }^{[14]}\end{array}$ & $\begin{array}{l}\text { High levels of cholesterol, Triglycerides, LDL, stones in the } \\
\text { gall bladder can be considered as Sama Meda Dhatu } \\
\text { Avastha }\end{array}$ \\
\hline Asthi & Various diseases that can occur due to it are & Porous condition of bones i.e., Osteoporosis, osteophyte \\
\hline
\end{tabular}




\begin{tabular}{|c|c|c|}
\hline & 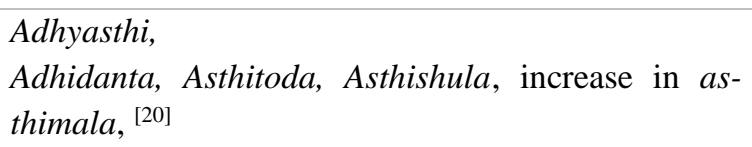 & $\begin{array}{l}\text { formation. Osteomyelitis, pagets disease are the conditions } \\
\text { in which accumulation of Ama is seen in Asthidhatu }\end{array}$ \\
\hline Majja & $\begin{array}{l}\text { Netrabhisyanda, Angalalima, Gaurava, Arushika, } \\
\text { Parvaruka, Tamodarshana, Murcha, Bhrama and } \\
\text { loss of normal functions. }{ }^{[14]}\end{array}$ & $\begin{array}{l}\text { Acquired Bone marrow depression which is caused by the } \\
\text { deposition of toxins liberated from certain infections are an } \\
\text { example of Sama Majja Dhatu. }\end{array}$ \\
\hline Shukra & $\begin{array}{l}\text { Klaibya, Aharshanam, Garbhajanakatvam, Alpay- } \\
\text { ushtvam, Garbhasrava etc. }{ }^{[14]}\end{array}$ & $\begin{array}{l}\text { A condition like pyospermia shows its association with } \\
\text { Ama. }\end{array}$ \\
\hline Purish & $\begin{array}{l}\text { Atidurgandhita, Shuksha mala pravrutti, Guru mala } \\
\text { (sinks in water), Ajirna, Vishtambhkara, Atipicchila, } \\
\text { Kuksi-Shulkara, Atopakara, Sashula Pravrtti, } \\
\text { Gauravakara and other disorders of udara may be } \\
\text { found. }{ }^{[14]}\end{array}$ & $\begin{array}{l}\text { Association of mucus in stool can be termed as Sama Puri- } \\
\text { sha. }\end{array}$ \\
\hline Mutra & $\begin{array}{l}\text { Bastipidana, Atyadhika Mutra Nirharana, Avila- } \\
\text { mutrata, etc. }{ }^{[14]}\end{array}$ & $\begin{array}{l}\text { It can be seen in Diabetes as a disorder where excessive } \\
\text { sugar is removed through the urine. }\end{array}$ \\
\hline Sweda & $\begin{array}{l}\text { Kandu, Twakruksta, Durgandhta etc. are produced } \\
\text { due to its Samavastha. }{ }^{[14]}\end{array}$ & \\
\hline
\end{tabular}

\section{DISCUSSION}

Ayurveda elaborated different concepts related to disease pathogenesis and Ama is one of them. Vagbhata was the first author to define Ama as a separate entity, but all Acharyas were having the same opinion that Ama is the root cause of many diseases.

After analysing the definitions about Ama following facts become clear about Ama.

1. Feeble action of Agni is the root cause for its production, but the Agni is not specified by most of the Acaryas. So, it is quite clear that anywhere in the body, if Agni is not working properly the Ama will be produced.

2. Ama is produced from Ahara Rasa when it is not properly digested. In the case of Jatharagnimandya, this Ahararasa is the undigested food but in the case of the rest of Agnis, it is the metabolites that are undergoing a process of metabolism by these Agnis.

3. Place of origin of Ama is given as Amashaya. But considering the presence of Agni at different levels Ama can be produced at different levels at different sites in the body.

Due to inhibition of Jatharagni if the ingested food is not properly digested and the products which arise out of such impaired digestion are being retained in the stomach, they undergo changes and yield toxic substances i.e., Ama. Also, the impaired Vata, Pitta and Kapha when mixed with one another lead to the formation of Ama Dosha. Another type of Ama is the Ama produced by ingestion of poisonous substances and produced due to external factors. Even the endotoxins produced by some parasites, bacteria etc. could be termed as Ama. Ama is not a single entity but is a generalised term that refers to various substances produced in the body which are harmful, in a way or another, to the body. Disturbed dietary habits, improper sleeping patterns, unethical conduct, excessive sexual indulgence, daytime sleep and lack of disciplinary living regimen, etc. are some factors that can lead to Agnimandya followed by the production of Ama. Ama generally affects Dosha, Dhatu and Mala by combining with them and causing diseases. Various properties like Asamyuktam, Avipakvam etc. are found in Ama which makes it the pathogenic factor. Ama not only clogs the digestive flow but because of its obstructive nature, clogs bodily channels (Strotas) and disrupts physiology including the formation and excretion of waste and it adversely influences the formation and functions of the tissues (Dhatu). At a cellular level, Ama may disrupt cellular movement, change cell membrane composition, inhibit shedding of membrane vesicles, disrupt cellular communication and membrane functions, and alter antigenantibody interaction and leads to improper antigen 
presentation causing derangement of the immune system resulting in autoimmunity or autoimmune like symptoms. According to Modern physiology, a variety of transforming and transmuting substances are present in the body like enzymes, hormones, catalysts, etc. When these are unable to function properly or entirely, different metabolites are formed which are not acquired by the body. On further process these go on accumulate in different systems, affecting the normal mechanism of that respective system. These may be considered as Ama. Also, endo or exotoxins of bacteria can be considered as Ama. On the basis of relation with Ama, Vikrtavastha of all Dosha, Dhatu and Mala are of two types viz. Samavastha and Amavastha. Ama has a great potential to vitiate all Dosha, Dushya and Mala to produce Samavastha. While due to metabolic defects caused due to Ama, the malformed Dosha, Dhatu and Mala are themselves termed as Ama. Stage of Sama Rasa can be seen clinically in the case of lymphadenitis in which due to any infection, exo- or endotoxins are produced in lymph and are filtered by lymph nodes and as result lymphadenitis is produced. Although the production of many diseases depends upon this pathogenic factor, still there is no objective parameter to identify the entity, Ama in the laboratory Many scholars of Ayurveda have proposed the theory of free radical as an important tool in evaluating the prevalence of Ama. Here this can also be said that Ama is not a single entity but is a group of substances that are harmful to the body. The relation of Ama with Dosha, Dushyas is very important in the context of the development of disease. It is seen that Dosha, Dhatu and Mala can be of two types of viz. Sama and Nirama. In Samavastha Dosha, Dhatu and Mala have no defects in their constitution, but they produce various diseases and symptoms due to their association with Ama. Whereas in Amavastha, the Dhatu mala and Dosha have constitutional defects in them and so they produce Rogavastha in the body. Various symptoms are produced in the body due to the prevalence of Ama. On the basis of these symptoms, all diseases can be classified in Samavastha and Niramavastha and the treatment of the disease depends upon these two stages.

\section{CONCLUSION}

Ama is generated at various levels in the body, which is at Jatharagni level, Bhutagni level, Dhatwagni level and also at the cellular level. Ama can be classified in various ways depending upon its action, Agni, site of production etc. Ama has no direct correlation in modern science but can be described as toxins or antigens which can trigger diseases pathogenesis. A definite line of treatment of Ama can be drawn after considering the causes, symptoms and severity of the condition.

\section{REFERENCES}

1. Sharma P.V., Charak Samhita (Text with English translation), Chikitsasthana, Adhayaya 15, Grahanidosha chikitsa adhyaya, Verse 3 , VI $^{\text {th }}$ Edition, Chaukhamba orientalia, Varanasi, 2000, Page No. 249.

2. Dr Tripathi Brahmanand, Astang Hradayam of Srimadvagbhata edited with Nirmala Hindi commentary, Nidansthana, Adhayaya 1, Sarvaroganidan Adhaya, Verse 1, Chaukhamba Sanskrit Pratishthan, Delhi, Reprint 2012, Page no. 429

3. Vannimadhav Shastri Joshi and Narayan Hari Joshi, Ayurvediya Shabdakosha, Pratham khanda, Maharashtra Rajya Sahitya aani Sanskruti Mandal, 1968, Page no 151

4. Shri Taranatha Tarkavachaspati, Vachaspatyam, Vol. I, Chowkhamba Sanskrit series office, Varanasi, Fourth Edition, 1990,

5. Dr Tripathi Brahmanand, Astang Hradayam of Srimadvagbhata edited with Nirmala Hindi commentary, Sutrasthana, Adhayaya 13, Doshopakramaniya Adhaya, Verse 25, Chaukhamba Sanskrit Pratishthan, Delhi, Reprint 2012, Page no. 188

6. Dr Tripathi Brahmanand, Astang Hradayam of Srimadvagbhata edited with Nirmala Hindi commentary, Sutrasthana, Adhayaya 13, Doshopakramaniya Adhaya, Verse 26, Chaukhamba Sanskrit Pratishthan, Delhi, Reprint 2012, Page no. 188

7. Sharma P.V., Charak Samhita (Text with English translation), Chikitsasthana. Adhayaya 15, Grahanidosha chikitsa adhyaya, Verse 44, VI $^{\text {th }}$ Edition, 
Chaukhamba orientalia, Varanasi, 2000, Page No. 253.

8. Pandit Sri. Brahma Sankar Misra, Bhava Prakasha of Shri Bhava Mishra, Edited with 'The vidyotini, Hindi commentary, Vol.2 ${ }^{\text {nd }}$, Chapter 26, Aamvatavyadhi adhikar, verse 5, Chaukhambha Sanskrit Bhawan, Varanasi, 2013.Page no. 278

9. Dr Tripathi Brahmanand, Madhav Nidanam (Roga Viniscaya) of Shri Madhavakara with Sanskrit commentary Madhukosa by Vijayrakshit and Srikanthadatta, Volume I, chapter 25, Aamvata nidan, Verse 1-5 Chaukhamba Surbharti Prakashan, Varanasi, Reprint 2005, Page No.574-575

10. Sharma P.V., Charak Samhita (Text with English translation), Vimansthana, Chapter 2, Trividhakukshiya Viman, Verse 8, VI ${ }^{\text {th }}$ Edition, Chaukhamba orientalia, Varanasi, 2000, Page No. 311.

11. Dr Tripathi Brahmanand, Astang Hradayam of Srimadvagbhata edited with Nirmala Hindi commentary, Sutrasthana, Chapter 13, Doshopakramaniya Adhaya, Verse 27, Chaukhamba Sanskrit Pratishthan, Delhi, Reprint 2012, Page no. 188

12. Dr Tripathi Brahmanand, Madhav Nidanam (Roga Viniscaya) of Shri Madhavakara with Sanskrit commentary Madhukosa by Vijayrakshit and Srikanthadatta, Volume I, chapter 25, Aamvata nidan, Verse 1-5 Chaukhamba Surbharti Prakashan, Varanasi, Reprint 2005, Page No.574

13. Dr Tripathi Brahmanand, Madhav Nidanam (Roga Viniscaya) of Shri Madhavakara with Sanskrit commentary Madhukosa by Vijayrakshit and Srikanthadatta, Volume I, chapter 1, Panchanidanlakshan, Chaukhamba Surbharti Prakashan, Varanasi, Reprint 2005, Page No.20

14. Sharma P.V., Charak Samhita (Text with English translation), Sutrasthana, Adhayaya 28, Vividhashitapitiyam adhyaya, Verse 9-19, VI ${ }^{\text {th }}$ Edition, Chaukhamba orientalia, Varanasi, 2000, Page No. 228-229.

\section{Source of Support: Nil Conflict of Interest: None Declared}

How to cite this URL: Archana Arun Kulkarni \& Rashmi Arvindkumar Dohare: Ama From Ayurvedic And Modern Perspective. International Ayurvedic Medical Journal \{online\} 2021 \{cited December 2021\} Available from: http://www.iamj.in/posts/images/upload/3055 3062.pdf 